\title{
Myofascial force transmission in the humans; a systematic scoping review of in-vivo studies
}

\author{
M.S. Ajimsha ${ }^{\star 1}$, Praveen J Surendran², Prasobh Jacob², Pramod D. Shenoy ${ }^{1}$, Mohammed Jamal Bilal ${ }^{3}$ \\ ${ }^{1}$ Department of Physiotherapy, Hamad Medical Corporation, Doha, Qatar; \\ ${ }^{2}$ Cardiac Rehabilitation Department, Heart Hospital, Hamad Medical Corporation, Doha, Qatar: \\ ${ }^{3}$ Southmead Hospital, -Bristol, UK \\ Corresponding author: MS Ajimsha (e-mail: ajimshaw.ms@ gmail.com).
}

\begin{abstract}
Background: The fascial system provides an environment that enables all body systems to operate in an integrated manner and is capable of modifying its tensional state in response to the stress applied to it. Recent in vitro, animal and cadaveric studies have shown that "myofascial force transfer" (MFT) has the potential to play a major role in musculoskeletal function and dysfunction. Objective: Human evidence for the existence of invivo MFT is scarce. This scoping review attempts to gather and analyse the available evidence of the in-vivo human MFT studies in order to sustain and facilitate further research and evidence based practice in this field. Methods: A search of most major databases was conducted with relevant keywords that yielded 238 articles as of August 2020. A qualitative analysis of the studies was conducted after rating it with Oxford's Center for Evidence -based Medicine (CEBM) scale. Result: Nineteen studies ranging from randomized controlled trials to case studies covering 540 patients were included in this review. The analyzed studies were highly heterogeneous and of lower methodological quality meddling with the quantitative analysis. Ten studies are confirming a 'most likely' existence of MFT, eight studies confirming it as 'likely' and one study couldn't confirm any MFT existence in this review. Conclusion: Findings from in vivo human studies supports the animal and cadaveric studies claiming the existence of MFT which need to be corroborated by the future high-quality studies. Forthcoming studies on MFT may give answers and solutions to many of the human musculoskeletal mysteries ordysfunctions.
\end{abstract}

INDEX TERMS Fascia; Myofascial force transfer; epimuscular force transfer

\section{INTRODUCTION}

Musculoskeletal pain and dysfunction are among the main reasons for visiting doctors, physiotherapists and osteopaths all over the world; it is also the most common cause of chronic long-term pain that affects countless people around the world (Woolf and Pfleger, 2003). As the prevalence of musculoskeletal pain increases with longevity in the sedentary population, we need to identify more justifiable causal relationships that may lead to the development and evaluation of new ways of managing these patients.

Fascia may simply be defined as a network of fibrous tissues that pervades the whole body and supports, surrounds, suspends, protects, connects and divides the musculoskeletal and visceral components of an organism (Kumka \& Bonar, 2012). Recent research has shown that fascia is the most innervated structure after the skin (Fede et al., 2020) and is extensively innervated by free nerve endings and post-ganglionic sympathetic fibers (Mense 2019). Besides possessing a potential role in proprioception and pain perception (Wilke et al., 2017), fascia has been demonstrated to connect mechanically the muscles of the human body (Huijing 2007; Yucesoy 2010), which challenges the classical concept of muscles as being morphologically independent actuators (single muscle theory) (Wilke et al., 2018). Many researchers have found the role of fascia of interest and importance in musculoskeletal disorders, due to its potential to influence muscle activity and continuity. (Ajimsha et al., 2020). Studies have already demonstrated the role of fascia as a connecting link between the skeletal muscles throughout the body that are linked to each other by fascial tissue forming a network with some specific patterns (Luomala and Pihlman, 2016; Wilke et al., 2016a) that can undergo dysfunction and pain if under or over used (Ajimsha et al 2020). 
The fascial system provides an environment that enables all body systems to operate in an integrated manner (Adstrum et al., 2017) and is capable of modifying its tensional situation in response to the stress applied to it (Bordoni and Simonelli, 2018; Wilke et al., 2017b) and it is believed that strain or force transmission could occur in certain directions in response to changes in muscle activity or length (Luomala and Pihlman, 2016; Norton-Old et al., 2013; Krause et al., 2016). It has been proposed that myofascial force transfer may play a major role in musculoskeletal function and dysfunction (Ajimsha et al., 2020).

Traditional anatomical descriptions usually do not consider the structural continuity of the connective tissue but recent in vitro and animal studies have shown that muscle forces not only transmitted to the tendons longitudinally (for example, in myotendinous junctions), but laterally to or between adjacent muscles by intermuscular mechanical interactions through collagen linkages between muscles and adjacent connective tissues and often referred to as "epimuscular myofascial force transmission (EMFT)”. (Huijing, 1999; Yucesoy, 2010; Ajimsha \& Shenoy 2019). These connective tissues can be endomysium, perimysium, epimysium, tendons, joint capsules, neurovascular tracts, fascia or even the viscera since fascia is ubiquitous across the body (Huijing, 2009; Karakuzu et al., 2017; Ajimsha et al., 2020). More simply EMFT refers to the transmission of muscle forces to the bone via pathways other than the classic muscle origin and insertion. (Maas \& Sandercock, 2010). Fascia connects muscle fibers to each other, muscle to another muscle and muscles to periarticular tissues, allowing intramuscular (through the muscle), intermuscular (force transmission between adjacent muscles via the connective tissue at their interface) and extramuscular (between the epimysium and the adjacent non-muscular structures) force transmission (Maas \& Sandercock, 2010; Huijing et al., 1998; Huijing \& Baan, 2003). Apart from the invasive animal studies that have proven the existence of myofascial force transmission, human cadaveric studies have also examined the potential force transmission between the components of myofascial chains (Krause et al., 2016). Although the experimental methods vary considerably, most of the studies are concluding that force applied to a local structure can substantially affect neighboring connective tissues and muscles (Wilke et al., 2016a).

Data gathered from animal studies do not necessarily translatable to human bipedal biomechanics. Force transmission studies from cadavers cannot be justifiable to in-vivo human myofascial force transmission as it may be influenced by a multitude of factors, including (but not limited to) force production, transmission, soft tissue length-tension relationships, muscular tone, connective tissue stiffness, neural factors and so on. Most of the research on cadavers has been carried out using cadavers from the elderly, (Krause et al., 2016), another factor which may alter the results of the study on force transmission. In contrast, in vivo studies conducted in clinical settings could provide valuable hints regarding the relative contribution of myofascial force transmission to the proper functioning of the movement system and it is the only reliable evidence that we can utilize for future clinical applications. Evidences from the emerging in vivo studies are really encouraging and pointing towards the existence of the myofascial force transmission in humans. (Marinho et al., 2017; Huijing et al., 2011; Pamuk et al., 2016; Pamuk and Yucesoy, 2015; Yaman et al., 2013). This scoping review attempts to gather and analyze available evidence for myofascial force transmission in humans to support and facilitate further research in this area.

\section{METHODS}

We searched the following electronic databases with no date limitations: MEDLINE, CINAHL, Academic Search Premier (ASP), Cochrane library, PEDro databases and Google Scholar for original research, including clinical trials, Systematic reviews, cohort studies, reviews, and case studies published in the English language. The search strategy was formulated using the term myofascial force transmission and epimuscular force transmission. The inclusion criteria were decided as any in vivo human studies analysing the key words. Studies on animal or cadaveric models were excluded as well as in vitro studies. Articles published in the form of editorials, expert opinions, informative articles or articles that do not contain sufficient information to complement an analysis have also been excluded. The relevant studies were identified, selected after screening the abstract, and saved as full text for further review. Two experienced reviewers performed the independent searches in April 2020 which was later updated in August 2020 and four reviewers completed the review process. No grey literature was included. The reference lists of the eligible publications and articles were screened for additional eligible publications. The lists were compared, and articles identified by both reviewers were collected in full text. A total of 238 artcles were found to be relevant by both examiners.

In order to rank the study quality, we have applied the Oxford's Center for Evidence -based Medicine (CEBM) scale (Oxford CEBM 2009) which categories the 
studies at various levels of evidence by assessing the quality based on the study design, which categorize the studies in a scale ranging from 1 to 5 with further subdivision for each. Systemic reviews with homogeneity of RCTs are classified at the highest levels, whereas expert opinions are the lowest. It has been decided that all the RCTs will be evaluated using the PEDro scale (Blobaum 2006), which evaluates methodological quality and consists of a checklist of 11 criteria, 10 of which are rated. In this review, studies with PEDro scores of 6 to 10 were considered to be of high quality, 4 to 5 were considered to be of moderate quality and 0 to 3 were considered to be of poor quality (Ajimsha et al., 2015).

\section{RESULTS}

Of the 238 studies identified in the original search, 19 were eligible according to the inclusion criteria (Fig. 1). The Rayyan QCRI web application was used by the authors to collaborate on the selection of studies and decisionmaking as part of this scoping review. The frame work recommended by Arksey and O' Malley (2005) and Levac et al., (2010) was used to conduct this review and PRISMA extension for scoping reviews (PRSIMA-ScR) (Tricco et al., 2018) was used as the reporting tool. Figure 1 illustrates the decision-making flow chart for this review. The selected articles were reviewed and the details like study design, study participants, aims, myofascial force experiment, region studied, intervention dose, outcome measures used and specific results were tabulated. The corresponding authors of the articles were communicated if there were missing data or for any kind of verification. The key characteristics and methodological details of the included studies are provided in Table 1.

\section{DATA SYNTHESIS}

de Bruin et al., 2011 conducted a clinical trial $(\mathrm{CEBM}=4)$ with 15 cerebral palsy patients with an objective to determine whether Flexor Carpi Ulnaris (FCU) muscle influences wrist torque even after tenotomy of its distal tendon. The maximum wrist torque was determined in vivo for patients with hemiplegic cerebral palsy in three conditions: 1) with the arm and the muscle intact; 2) after tenotomy of the FCU just proximal to the pisiform bone; and 3) after dissection of the belly of the muscle from its fascial surroundings. Following FCU muscle tenotomy, the maximum wrist torque decreased by $18 \%$ and muscle dissection led to an additional $18 \%$ decrease. The authors concluded that, despite the tenotomy of its distal tendon, FCU still contributes to the flexion torque at the wrist and attribute this to the transmission of extramuscular myofascial force. The study is having its own methodological and sampling issues (selection, performance and detection biases) that could seriously interfere with its generalizability but appreciable for its innovativeness.

In 2012, Tiane et al., Conducted an experimental trial $(\mathrm{CEBM}=4)$ to determine to what extent passive changes in the length of the Gastrocnemius muscle, induced by knee motion, affect adjacent Soleus muscle tension. Simultaneous ultrasound imaging of the gastrocnemius and soleus muscles was obtained during passive knee flexion $\left(0-90^{\circ}\right)$, while maintaining the ankle angle of $70^{\circ}$ or $115^{\circ}$ in 15 healthy volunteers. Image correlation analysis was applied to quantify muscle fascicle lengths in both muscles. This study concluded that there was a certain intermuscular force transmission between the medial Gastrocnemius muscle and the Soleus muscle during passive knee extension. The authors explain that this phenomenon by means of force transfer due to shortening of the distal Achilles tendon and a direct epimuscular force transmission via the connective tissues between the medial Gastrocnemius muscle and the Soleus muscle. Again, the small sample size and a non-randomized study methodology limits its generalizability.

In 2013, Yaman et al., conducted a clinical trial $(\mathrm{CEBM}=4)$ in five healthy individuals to investigate the hypothesis that changes in overall length of the Gastrocnemius muscles in vivo will result in significant and heterogeneous local tension within in all lower limb muscles in humans. They placed the subjects in the prone position with the ankle attached at 90 degrees with the help of the AFO, allowing the hip and knee to move ( $\Delta$ knee angle $\approx 25^{\circ}$ ) within a high resolution 3D MRI scanner. The movement of the hip and knee caused significant and heterogeneous local tension not only to the Gastrocnemius muscle, but also within the synergistic and antagonistic muscle, although it was kept at a constant muscular tendon complex length. Despite its inherent methodological limitations, this study is a good starting point for future high-quality studies to verify the existence of in vivo epimuscular myofascial force transmission.

The transmission of myofascial force from Latissimus Dorsi (LD) to contralateral Gluteus Maximus (GMax) through Tensor Fascia Lata (TFL) was an interesting study led by do Carmo Carvalhais et al., in 2013 with 37 healthy volunteers attached to an isokinetic dynamometer $(\mathrm{CEBM}=3 \mathrm{~b})$. The objective was to assess if the active or passive tension of the LD resulted in an increase in the passive tension of the contralateral GMax, indexed by changes in hip rest position (RP) or passive 
stiffness. This study revealed that forces had been transmitted from the LD to the contra lateral GMax modifying the hip PR, which supported the hypothesis. The author also reported that the functional relationship between the GMax and the hip joint was responsible for the observed effects after LD tensioning and proposed future studies which can verify the magnitude of force transmission between the LD and GMax along with the TLF stiffness. Again, the study was of low quality because of methodological flaws and the small sample size limiting its acceptance.

Inspiring from the above study, Joseph et al., in 2014 conducted an experimental matched controlled trial $(\mathrm{CEBM}=3 \mathrm{~b})$ with 40 participants, to investigate the effect of sacroiliac joint dysfunction (SJD) on contralateral Glenohumeral joint (GHJ) and found that SJD contributes to excessive anterior translation of humeral head (ATHH) in the contralateral GHJ. The investigators used a translational force of a push-pull dynamometer at the posterior part of the humeral head to passively translate the humeral head to the point of end feel while using a realtime ultrasound to evaluate this translation. This study confirmed the existence of an association between the sacroiliac joints and the contralateral GHJ. The authors are justifying the result by means of myofascial force transmission and mentioning it as "oblique sling muscles". They concluded that the sacroiliac joint should be assessed for any contralateral shoulder joint malfunction and vice versa. Given the small sample size, selection, performance and detection biases, the study results cannot be generalized. The author did not take into account the level of physical activity of the participants (both groups) that can affect the outcome.

In 2015, Grieve et al., investigated the immediate effect of a single application of Self Myofascial Release (SMR) on the plantar aspect of the foot on hamstring and lumbar spine flexibility. A pilot single-blind RCT $(\mathrm{CEBM}=2 \mathrm{~b}$; Pedro= 4/10) was conducted on 24 healthy volunteers. They observed a significant increase in hamstring and lumbar spine flexibility when compared to the control group, with a large effect-size as measured with a sit and reach test done by evaluators blinded to the group allocation. He suggested that flexibility interventions based on myofascial chains, in particular the superficial back line (SBL), induce the transmission of force along the myofascial chain resulting in non-local effects. This study used appropriate methods of randomization and concealment, but did not blind participants and presents problems of generalization because of the small sample size, the use of healthy participants and a less reliable outcome measure.

Cruz-Montecinos et al., in 2015 conducted a clinical trial $(\mathrm{CEBM}=4)$ on 17 asymptomatic, sedentary young male individuals to assess the relationship between pelvic motion and deep fascia displacement in the medial gastrocnemius (MG), when seated with an extended dominant limb while doing pelvic anteversion. The displacement of the MG deep fascia was evaluated through automatic tracking with an ultrasound while angular variation of the pelvis with a $2 \mathrm{D}$ kinematic analyzer. The study found a positive relationship between pelvic movement and MG fascia displacement. The results reaffirm the concepts of myofascial force transmission by synergistic muscle groups and the role of fascia in restricting movement in far-flung areas. This study, while lacking methodological rigour, has led to a futuristic result that can be explored in greater depth.

In 2016, Wilke et al., evaluated the remote effects of lower limb stretching on cervical range of motion (ROM) and found that lower limb stretching leads to improvements in cervical ROM and provides some insight into the existence of myofascial force transmission in vivo. It was a pilot study with 26 healthy participants in a matched-pair comparison model $(\mathrm{CEBM}=3 \mathrm{~b})$ with an experimental group $(n=13)$ undertaking a single session of static stretching for the Gastrocnemius and the Hamstrings to an age- and sex-matched control waiting list group ( $\mathrm{n}=$ 13). They measured the pre- and post-intervention, maximal cervical flexion / extension ROM and found substantial changes in the experimental group's cervical ROM relative to control. The authors pointed to this finding as evidence of tension transfer along the myofascial channels. Since the result is obtained from a non-randomized small group analysis, it is prudent to generalize the result. As a continuation of the same, Wilke et al., in 2017, conducted a medium quality $(\mathrm{CEBM}=2 \mathrm{~b}$; PEDro= 6/10) randomized controlled study on sixty-three healthy participants to compare the same, but with three groups, remote stretching of the lower limb (LLS), local stretching of the cervical spine (CSS) and inactive control (CON) groups. Both LLS and CSS increased cervical ROM compared to the control group in all movement planes and at all measurements $(\mathrm{P}<$ .05). Between LLS and CSS, no significant changes were observed $(\mathrm{P}>.05)$. Methodological flaws and inadequate power hinders the study's generalizability. The authors have been cautious in the interpretation section as "the effects achieved do not appear to be specific to the direction, further research is required to provide evidence-based recommendations." 
Changes in length in the muscle fibre direction, provide essential information for the characterising muscle function. Pamuk et al., (2016) used a combination of magnetic resonance (MR) imaging based deformation analyses and diffusion tensor (DT) imaging based tractography, to assess muscle fibre direction and local tissue deformations within the human medial gastrocnemius (GM) muscle $(\mathrm{CEBM}=4)$. Five healthy female subjects were placed in prone position inside the MR scanner in a relaxed state with the ankle angle set at $90^{\circ}$, knees flexed at $140^{\circ}$ and then to an extended position. High-resolution 3D MRI and DT image sets were acquired in these two positions, allowing local deformations to be computed along the muscle fascicles. The results suggest that the mean deformation errors are much lower than the mean direction strains of the fiber. Moreover, shortening and lengthening occurred at the same time along individual fascicles despite imposing GM lengthening. The presence of large amounts of shear between the fascicles was confirmed by shear strains along the fibres, and the authors suggested that an inhomogeneity of the fibre strain was indicative of transmission of epimuscular myofascial force. The study is not without limitations though, such as a very small sample size, the tracts obtained are representative of muscle fascicles and not individual muscle fibres, and measurements performed in a passive state of muscle. Nevertheless, this study provides a powerful tool for quantifying deformation along human muscle fibers in vivo which can help to get a much better understanding of normal and pathological muscle function and mechanisms of treatment techniques.

Karakuzu et al., 2017 conducted a small-group experimental study $(\mathrm{CEBM}=4)$ to investigate intermuscular mechanical interactions (strain transfer) of human medial Gastrocnemius (GM) using combined magnetic resonance and diffusion tensor imaging. The purpose was to examine the hypothesis that submaximal plantar flexion activity at $15 \%$ maximal voluntary capacity (MVC) causes heterogeneous length changes along the fascicles of human GM muscle of healthy female subjects (five). The authors found that the proximal route segments were shortened and the distal portions of GM were lengthened with heterogeneity in the mean fibre directions. There is intersubject variability in the magnitude and distribution of fascicles strain. The authors concluded that sub-aximal activation of GM in the extended knee position causes heterogeneous deformation distributions, including local elongation that supports the theory of functionally dependent invivo muscle mechanics. More studies are needed to determine the cause of this heterogeneity (e.g.:- transmission of epimuscular force). According to the authors, this was the first study of this type that quantified local deformities along the human skeletal muscle by sustained sub-aximal activation. The study result cannot be generalizable due to its inherent limitations posed from the study methodology, sample size, anatomical variations including Inter-subject variability of fascicle strain, issues with joint positions, muscle activation levels, complexity and individual differences of the epimuscluar connections, but can be an ideal starting point to introduce high quality future trials in this direction.

Finni et al, in 2017 conducted an in vivo experimental study (CEBM=4) among 11 healthy volunteers to examine whether activation could alter the shear between the soleus (SOL) and lateral gastrocnemius (LG) muscles in vivo in order to determine the norm 'the lateral connections between muscles provides pathways for myofascial force transmission'. They investigated whether the activation of the SOL and LG muscles could modify the shear between the two. The participants underwent a series of knee joint manipulations to obtain the plantar flexion force, LG, and SOL muscle fascicle lengths and relative displacement of aponeuroses between the muscles. The data was acquired over the entire range of passive movement, a $20^{\circ}$ stretch of knee extension in both passive and active phases created by selective electrical stimulation of the LG. During active stretching, the plantar flexion force was $22 \%$ higher and the relative movement of the aponeurosis was smaller than during passive stretching. The changes in soleus length did not differ between passive and active stretches, but the LG fascicles stretched less in the active state than in the passive state when the stretch began at $70^{\circ}$ and $90^{\circ}$ knee flexion. The activity-induced diminution in the relative displacement of SOL and LG suggests stiffer connectivity between the two muscles, at least at flexed knee joint angles, attributable to myofascial force transmission. It is invariably difficult to conclude and generalize results from smaller, low methodological quality studies as it can create super realization biases and even can lead to faulty assumptions, but appreciable as 'proof of concepts'.

Several researchers have already demonstrated the effects of human myofascial force transmission in vivo in terms of strain, but no force, with some exceptions, such as research by do Carmo Carvalhais et al., in 2013 demonstrating force transmission in vivo, through changes in joint kinetic variables. The study of Marinho et al., (2017) was designed to test how simultaneous changes in knee and hip positions change the resting position of the ankle and the passive torque $(\mathrm{CEBM}=4)$. They recruited 37 
subjects that underwent an isokinetic assessment of ankle passive torque. They carried out these measurements under three test conditions: $0^{0}$ at knee and $0^{\circ}$ at hip; $90^{\circ}$ at knee and $90^{\circ}$ at hip; and $135^{\circ}$ at knee and $120^{\circ}$ at hip. The results demonstrated that the ankle resting position moved towards dorsiflexion when knee/hip position changed from $0 \% / 0^{0}$ to $90^{\circ} / 90^{\circ}$ and moved towards plantar flexion when knee/hip position changed from $90^{\circ} / 90^{\circ}$ to $135^{\circ} / 120^{\circ}$, attaining values closer to the position of $0^{\circ} / 0^{0}$. Similarly, passive torque diminished when knee/hip position changed from $0^{0} / 0^{0}$ to $90^{\circ} / 90^{\circ}$, but it enlarged when knee/hip position changed from $90^{\circ} / 90^{\circ}$ to $135^{\circ} / 120^{\circ}$. The action of isolated two joint muscle-tendon units crossing both the knee and ankle would not support the reversion of resting position and the passive torque behaviour when knee/hip position changed $90^{\circ} / 90^{\circ}$ to $135^{\circ} / 120^{\circ}$. Consequently, forces originated from continuous structures crossing the hip, knee and ankle potentially contributed to this outcome.

While Marinho et al., experimented the influence of proximal joint positions on distal joint resting position and passive torque, another researcher Yoshitake et al., in 2018, experimented the existence of epimuscular myofascial force transmission in human upper extremity $(\mathrm{CEBM}=4)$. They examined whether manipulating the angle of a joint to stretch the muscle can alter the shear modulus of an adjacent muscle at rest, and whether there are regional differences in this response. They selected two neighbouring muscles, Biceps brachii (BB: manipulated muscle) and Brachialis (BRA: resting adjacent muscle), because they had independent tendons attached to different bones. The study was conducted with 13 healthy young men and measured BB and BRA shear modulus with shear wave elastography to proximal and distal muscle regions with forearm supine, Neutral and pronation while maintaining the elbow joint at $100^{\circ}$ or $160^{\circ}$ angle. The authors added that the observed alteration of the adjacent resting muscle shear modulus may be due to the EMFT in the upper limb, and suggested that this force transmission could be facilitated by muscle at its stretched lengths. Although the study is of low methodological quality, the clinical implication of these findings may be attributed to the efficacy of interventions such as myofascial release techniques which aim to mechanically release intermuscular mechanical interactions.

In 2018, Ateş et al., conducted an experimental analysis $(\mathrm{CEBM}=4)$ to quantify the localized changes in the shear modulus of the lateral gastrocnemius (GL), monoarticular dorsi- and plantar-flexor muscles induced by a change in knee angle. Two experimental sessions were performed in this study. The experiment one $(n=11)$ assessed the effect of knee angle on shear modulus on GL and soleus (SOL) muscle. Experiment two $(n=10)$ evaluated the effect of knee angle on the shear module on the GL muscle, Peroneus Longus (PERL) and Tibialis Anteroir (TA). Participants underwent slow, passive ankle rotations at the following two knee positions: knee flexed at $90^{\circ}$ and knee fully extended. Ultrasound shear wave elastography was used to assess the muscle shear modulus of the GL, SOL [SOL-proximal and SOL-distal], PERL, and TA. A comparison was made of the shear modulus of each muscle between the two knee positions. This study provides evidence for significant intermuscular mechanical interaction or force transfer between human leg muscles during passive ankle rotations. The limitation reported in this study was that myoelectric activity had not been evaluated to ensure that muscle activity remained passive. As has been mentioned in other studies, we need high quality randomized trials to ascertain these findings.

Wilke et al., (2019) performed an experimental regression study $(\mathrm{CEBM}=3 \mathrm{~b})$, which looked into the age dependency of remote exercises on MFT. Using a pre- post regression method, the authors analyzed the influence of age on MFT in 168 healthy individuals between the ages of 13 and 87. Participants were asked to perform a single 120second SMR of the plantar fascia in the standing position and then to test the extensibility of the hamstring measured using a sit-and-reach test. Multinomial regression analysis found that SMR improved the hamstring extensibility by 10.1 percent with 58.9 percent of participants attaining a clinically significant improvement. The authors concluded that only the age and baseline flexibility predicted changes in the extensibility of the hamstring and that no relationship to sex, amount of physical activity, size, BMI, time of the day, etc. had been observed. The research has its limits on the outcome measures used and deserves physiological, morphological and functional tests to categorize and explain these unique results (neuronal, psychological, etc.). The authors expressed concern about the quality of the study and the confounding factors that might affect the outcome, and suggested high quality RCTs to verify these results.

Diong et.al. (2019) was the first to measure the magnitude and direction of changes in force resulting from passive Intermuscular force transfer between human Flexor Pollicis Longus (FPL) and the index finger part of Flexor Digitorum Profundus (FDP) in humans. To investigate this, they compared finger flexion force produced by passive thumb flexion in fifteen healthy subjects after one of the 
three conditioning protocols: passive thumb flexionextension cycling, thumb flexion maximal voluntary contraction (MVC), and thumb extension stretch $(\mathrm{CEBM}=4)$. Finger flexion force soared after all three conditions. In comparison to passive thumb flexionextension cycling, change in finger flexion force was less after thumb extension stretch, but not after thumb flexion. According to the authors, as muscle conditioning altered finger flexion force caused by passive thumb flexion, the change in force is likely due to intermuscular force transmission. They cited that their findings need to be interpreted in context of methodological limitations. First, passive force in FPL in vivo was not known and cannot be directly measured in humans except during invasive surgical procedures. Similarly, activity in the deep FDP may have contributed to index finger force. Unfortunately, activity in these muscles were not recorded. Also this study could not explain why faster thumb motion during cycling did not cause larger intermuscular force transmission compared to MVC. Not knowing or unable to explain how thumb motion influences index finger force or motion of FPL can be considered as a major limitation of this study.

Freitas et al., in 2019 conducted an in vivo experimental study $(\mathrm{CEBM}=3 \mathrm{~b})$ with 12 healthy and recreationally active male individuals to examine the existence of epimuscular myofascial force transmission between the quadriceps muscles during passive knee flexion. They compared the shear modulus of Vastus Medialis (VM), Vastus Lateralis (VL) with the hip flexors at two lengths by manipulating the hip position (flexed at $80^{\circ}$ and in neutral. This study showed no difference between hip positions in VM and VL shear modulus. This study also reported that the VL exhibits the highest shear modulus when the hip is flexed and it was highest in rectus femoris (RF) when the hip was in neutral position. The authors concluded that (i)changes in force may only occur at a connective tissue level surrounding the muscles and do not achieve the muscle bellies, (ii) the force transmission among the quadriceps muscles during passive stretching in healthy people is negligible, regardless of the degree of muscle lengthening and (iii) It cannot be concluded that the possibility that there is epimuscular myofascial force transmission between the quadriceps closer to patellar tendon, as the aponeurosis from the quadricep muscle components merge onto patellar tendon. The author has also mentioned about the confounding factors like stiffness difference between the synergistic muscle depending upon the type of population (trained or untrained, athletes or clinical population) and proposed that future studies should examine if the epimuscular myofascial force transmission during a passive stretching condition mainly occurs at a connective tissue level, and only occur within the muscle belly for higher levels of myofascial stretch (e.g., by evoking greater knee flexion).

Wilke et al., in 2020, published findings from an experimental study $(\mathrm{CEBM}=4)$ which for the first time visualized the MFT between serially connected skeletal muscles objectively. The purpose of this trial was to examine the impact of ankle motion on soft tissue displacement of the dorsal thigh. Eleven healthy active individuals, in prone position and with the knee extended, underwent passive calf stretches (ankle dorsal extension) imposed by an isokinetic dynamometer. High-resolution ultrasound was used to simultaneously capture the displacement of the semimembranosus muscle, which was quantified by means of cross-correlation analysis. Inactivity of the leg muscles was controlled using surface electromyography (EMG) and found that ankle dorsal extension induced substantial caudal muscle displacements $(p<0.0001)$ and found a strong association between maximal dorsal extension and semimembranosus motion. This study confirms mechanical force transmission between serially connected skeletal muscles. The authors are relating this findings to the earlier studies showing remote exercises effects. (Grieve et al., 2015; Wilke et al., 2016, 2017, 2019). Again this study need to be replicated with a sound methodological study to establish the presence of MFT.

\section{DISCUSSION}

Nineteen studies covering 540 patients were included in this review. The included studies ranged from randomized controlled trials to case studies. The sample size varied from 5 to 168 with an average of 28 (SD 36). The analyzed studies were highly heterogeneous and of lower methodological quality, ranging from $2 b$ (individual cohort studies and low quality RCTs) to 4 (poor quality cohort, case control studies and case series or poor or studies with non-independent reference standards) as per the Oxford's Center for Evidence -based Medicine (CEBM) grading scale. Twelve out of nineteen studies were of the grade of four. Five studies were of grade $3 b$ (individual case control studies/ nonconsecutive studies including cohort of very limited population, analysis based on limited alternatives), and two studies of grade $2 b$ (individual cohort studies and low quality RCTs). The reason for this low grading could be that, the most of the studies obtained were either a hypothesis tester or a proof of the concept trial. (Table 1). This implies that the deriving evidences from the current quality of studies or generalization into the existence of MFT is almost 
impossible with the current level of trials. At this point, a meaningful quantitative analysis is impractical and the review need depends more on the qualitative interpretations of the findings and hence, the reviewers decided to proceed the study as a 'scoping review'.

The included studies were spanning from the year 2011 to 2020 with two RCTs, one each case control, matched-pair and regression analyses and, 14 single group pilot experimental studies. Out of 540 participants across all the studies, 87 participants were from the RCTs and the rest of all (453 participants) were from the remaining study groups (17 trials). Most of the trial participants were healthy individuals except two trails, one of which had 20 participants with sacroiliac dysfunction (Joseph et al., 2014) and the other one had 15 cerebral palsy males (de Bruin et al., 2011) as the participants.

Out of the 19 trials, nine studies were focusing the MFT of the lower extremities and three of them on the upper extremities. The extremity studies were focused mainly on the EMFT concept. Seven trials were testing the serial distribution of the MFT across the muscle (longitudinal MFT). Five among them were analyzing the existence of MFT through the posterior fascial connectivity and two studies were focusing the MFT through the trunk with the oblique connectivity of upper \& lower extremities. Most of the studies were using ultrasound as the outcome measure while some were using MRI based technologies and only a few used musculoskeletal techniques as the outcome measures.

In order to draw a conclusion from such studies we have used a simple grading system ranging from 'less likely, likely to most likely' to explain the findings of the studies. The term 'less likely' represents a lack of evidence for MFT and 'most likely' represents a significant study confirmation of the MFT existence. The analysis revealed ten studies are confirming the existence of MFT as 'most likely', eight studies confirming it as 'likely' and one study couldn't confirm the existence of MFT (less likely). The results of the studies were encouraging, particularly with the studies utilizing objective outcome measures including high quality ultrasounds and real time radiological tracking of the MFT.

The ten studies confirming the existence of MFT are heterogeneous and varies from RCT to simple experimental trials with 221 participants at an average of 22 (SD 18). This includes an RCT $(\mathrm{CEBM}=2 \mathrm{~b})$, a matched pair intervention $(\mathrm{CEBM}=3 \mathrm{~b})$, and rest all (eight studies) were experimental studies without a control or comparison group $(\mathrm{CEBM}=4)$. Even though the studies are confirming highly significant MFT existence, the methodological under quality limits its generalizability and should practice caution in its interpretation. The RCT that confirms the MFT existence was a medium methodological quality trial (CEBM: 2b; PEDro: 6/10) from Wilke et al., (2017), completed with sixty-three healthy participants and found 'most likely' existence of MFT through the posterior fascial connectivity using a real time ultrasonic 3D movement analysis. This RCT was an extension of Wilke et al., 2016 study which was testing the same by means of a controlled, matched-pairs analysis. Cruz-Montecinos et al., (2015) and Wilke et al., (2020) had visualized longitudinal and remote effect of MFT in the lower extremities and claimed that local alterations of the mechanical tissue properties may modify flexibility in the neighboring joints. do Carmo Carvalhais et al., in 2013, confirmed longitudinal MFT between the latissimus dorsi (LD) and contra lateral gluteus maximus (GMax) through TFL by using an isokinetic dynamometer on 37 individuals. Experimental trials by Yaman et al., (2013); Pamuk et al., (2016); Marinho et al., (2017); Karakuzu et al., (2017) were highlighting 'most likely' existence of EMFT on the lower extremities while Diong et al., (2019) confirms the same between the thumb and the index finger.

Eight studies concluded the 'likely' existence of MFT, including a pilot RCT (CEBM= 2b; PEDro: 4/10)), a regression $(\mathrm{CEBM}=3 \mathrm{~b})$ and a case control trial $(\mathrm{CEBM}=$ $3 b)$. The rest were of single group experimental analysis $(\mathrm{CEBM}=4)$. The pilot RCT by Grieve et al., 2015, suggested 'likely' existence of MFT through posterior fascial connectivity when assessed post self myofascial release (SMR) with a sit and reach test compared to a control. In 2019, Wlike et al., has done a similar study on 168 healthy individuals using a regression analysis supported the 'likely' occurrence of MFT through the posterior fascial connection and by using same outcome measure. The case control study by Joseph et al., 2014 was pointing towards the likelihood of altered myofascial force transmission between Sacroiliac joint and contralateral GHJ in individuals who are having sacroiliac joint dysfunction. The studies by Tian et al., (2012); Finni et al., (2017); Ateş et al., (2018) were proposing the probability of MFT especially EMFT on the lower extremities while Yoshitake et al., (2018) and de Bruin et al., (2011) were proposing the same in the upper extremities. Freitas et al., 2019, with a small number of population studied the shear modulus of Quadriceps using shear wave elastography and reported 'no change' in the shear modulus between two hip positions during passive knee flexion and stated that EMFT (at a muscle belly level) does not occur between the quadriceps muscles when passively flexing the knee until 90 but 
suggested further studies to examine the occurrence of EMFT with greater muscle stretches and with different hip and knee positions.

It seems sensible that in the authors' qualitative synthesis, the best evidence would be derived from the existing higher quality studies, which probably have the less biased results. Unfortunately, there is a dearth of such studies at present. Even though the levels of evidence in this review may be considered arbitrary, it seems unlikely that a different review approach or grading system would have resulted in a different conclusion (Ajimsha et al., 2020). Although efforts were made to gather most of the published studies, some relevant trials might have been missed. Due to resource and language constraints, only publications in the English language were considered in this review and no effort was made to identify any unpublished trials. The included studies were very heterogeneous in terms of the MFT definition, study design, trial procedures, body regions, movements, protocols, sampling, outcome measures, and/or the presentation of data. Even though the majority of the studies were given positive evidence regarding the existence of MFT, one can't confidently claim the occurrence MFT nor can generalize the present findings. The current data can only be pooled as an 'emerging evidence' of the in vivo existence of MFT in humans that need to be established by future quality studies.

It is impossible to actively encourage the utilization of the available positive results of MFT to justify the clinical practice because of the limited capacity of health systems to absorb the new evidence and implement the necessary measures to do away with the obstacles hampering translation of the results of theory into practice. With underpowered sample sizes and the heterogeneity of the studies, we cannot argue that the MFT is the reason of many musculoskeletal mysteries but only suggest that there is 'some initial positive' findings of the MFT existence.

Clinician may use the concept of MFT as a justifiable aspect of their managements, but they should be aware that the functional implications are yet to be studied (Wilke et al., 2016). Currently, an increasing number of researchers and manual practitioners show continued interest and enthusiasm on the subject of myofascia and its force transmission, hence we can expect that high quality future studies with strong evidences might ascertain the existence of MFT. The objective reality of MFT might serve as a breakthrough in explaining several phenomena that lack a clear understanding of their etiology or pathophysiology even today. Clinicians may use the MFT as a way to rationalize the phenomenon's like referred and nonspecific pains which are often difficult to explain, and even can use as a concept to explain their treatment effectiveness. Even if we can explain such musculoskeletal dysfunctions and pain with strong evidence of MFT, we need to practice caution in generalizing it, as for example mobilizing fascia on the left leg decreases pain in the right leg ( $\mathrm{Sj}$, Aboodarda et al., 2015; Wiewelhove et al., 2019). Fascial research is moving forward into a level of acquiring new perspectives and horizons and we should believe that the technological advancement can explore much more in this field so that many of the bodily disorders and derangements can be demystified.

To have the high quality evidence, we need to appraise and organize the studies with good quality designs. Participants should be randomized, the design should be double blinded (Ajimsha and Shenoy, 2019). Usage of apriori calculated sample sizes; adequate power; limiting the sources of bias; appropriate levels of significance; assessing the threats to statistical validity; appropriate registration and the usage of technologies and radiological outcome measures may revolutionize the future of this field of research. We need to abstain from reporting within group differences as evidence of effectiveness (Matthews and Altman, 1996; KF Schulz et al., 2010). One should understand that_a systematic review or meta-analysis isn't essentially higher than a well-conducted RCT, and not all RCTs are essentially greater than observational trials of sound methodological quality (Ajimsha and Shenoy, 2019). Practitioners should utilize their critical appraisal skills to decipher any research findings before applying it to clinical practice._These recommendations would support inferences of clinically meaningful results and facilitate future metaanalyses and recommendations in this field. In all clinical trials, we support the current appeals for transparency and advocate journal adherence to the reporting guidelines. (Hoffmann et al., 2014; Chan et al., 2014).

\section{LIMITATIONS OF THE STUDY}

In spite of our best efforts to perform this review, it has several limitations that are inherent to any scoping review such as paucity of methodological rigor and a higher level of critical appraisal. Scoping review is a valuable tool in the ever-increasing collections of evidence synthesis methods, and we agree that it is an ideal method when it comes to finding new knowledge, gaps, scoping a body of literature, clarifying concepts, or investigating a research (Munn et al., 2018). We believe the following limitations may have some impact on the outcome of the review. Firstly, we had limited our search to human in-vivo studies having specified keywords only, as stated in the 
methodology. This was necessary to set fixed key words for the literature search in order to remain focused. It may however be possible that a few studies on MFT research would have become available with the input of a different set of keywords. Nevertheless, to our knowledge, there are no other known keywords available that is defining the concept of MFT. Secondly, exclusion of grey literature and non-English studies could have some impact on the results. Due to heterogeneity, methodological diversity and under quality, other scoring scales for methodological quality and biases couldn't be used. The majority of the studies analyzed involved a single group of cross sectional type experimental trials with a point of measure and results, and it is difficult to establish causal relationships based on these outcomes. Only an estimation of the prevalence of the process or phenomenon can be obtained by analyzing such studies (Setia 2016). Adherence to the qualitative appraisal always has its own limitations, including interpretation and social biases. We believe, usage of multiple reviewers might have reduced the "reviewer biases" to a keen extent. We encourage readers to critically appraise the research evidence prior to their application to clinical practice.

\section{CONCLUSION}

Although this scoping review gives positive results for the existence of myofascial force transfer, several aspects need to be clarified and thoroughly analyzed. We need high-quality, in vivo randomized controlled trials and biomechanical studies to ascertain the above findings, because the current studies are either in non-randomized format or with inadequate methodological quality and sample size that prevents generalizability of results. Future research should focus on determining the existence of myofascial force transmissions more objectively and reliably, which could not be fully evidenced in the work cited in this review. The upcoming studies on MFT may give answers to many of the human musculoskeletal mysteries or dysfunctions. Practitioners may use the concept of Myofascial force transmission as a compelling justification, but need to be vigilant in ensuring that its mechanism and functional implications remain to be explored.

\section{DECLARATION OF CONFLICT OF INTEREST}

The authors report no declarations of interest.

\section{REFERENCE}

1. Adstrum, S., Hedley, G., Schleip, R., Stecco, C., Yucesoy, C.A., 2017. Defining the fascial system.
J. Bodyw. Mov. Ther. 21, 173-177. https://doi.org/10.1016/j.jbmt.2016.11.003

2. Ajimsha, M.S., Al-Mudahka, N.R., Al-Madzhar, J.A., 2015. Effectiveness of myofascial release: systematic review of randomized controlled trials. J. Bodyw. Mov. Ther. 19, 102-112. https://doi.org/10.1016/j.jbmt.2014.06.001

3. Ajimsha, M.S., Shenoy, P.D., 2019. Improving the quality of myofascial release research - A critical appraisal of systematic reviews. J. Bodyw. Mov. Ther. 23, 561-567. https://doi.org/10.1016/j.jbmt.2019.03.011

4. Ajimsha, M.S., Shenoy, P.D., Gampawar, N., 2020. Role of fascial connectivity in musculoskeletal dysfunctions: A narrative review. J. Bodyw. Mov. Ther. 24, 423-431. https://doi.org/10.1016/j.jbmt.2020.07.020

5. Arksey, H., O’Malley, L., 2005. Scoping studies: towards a methodological framework. Int. J. Soc. Res. Methodol. 8, 19-32. https://doi.org/10.1080/1364557032000119616

6. Ateş, F., Andrade, R.J., Freitas, S.R., Hug, F., Lacourpaille, L., Gross, R., Yucesoy, C.A., Nordez, A., 2018. Passive stiffness of monoarticular lower leg muscles is influenced by knee joint angle. Eur. J. Appl. Physiol. 118, 585593. https://doi.org/10.1007/s00421-018-3798-y

7. Blobaum, P., 2006. Physiotherapy Evidence Database (PEDro). J. Med. Libr. Assoc. 94, 477478.

8. Bordoni, B., Simonelli, M., n.d. The Awareness of the Fascial System. Cureus 10. https://doi.org/10.7759/cureus.3397

9. Carvalhais, V.O. do C., Ocarino, J. de M., Araújo, V.L., Souza, T.R., Silva, P.L.P., Fonseca, S.T., 2013. Myofascial force transmission between the latissimus dorsi and gluteus maximus muscles: an in vivo experiment. J. Biomech. 46, 1003-1007. https://doi.org/10.1016/j.jbiomech.2012.11.044

10. Chan, L., Heinemann, A.W., Roberts, J., 2014. Elevating the quality of disability and rehabilitation research: mandatory use of the reporting guidelines. Am. J. Occup. Ther. Off. Publ. Am. Occup. Ther. Assoc. 68, 127-129. https://doi.org/10.5014/ajot.2014.682004 
11. Cruz-Montecinos, C., González Blanche, A., López Sánchez, D., Cerda, M., Sanzana-Cuche, R., Cuesta-Vargas, A., 2015. In vivo relationship between pelvis motion and deep fascia displacement of the medial gastrocnemius: anatomical and functional implications. J. Anat. 227, 665-672. https://doi.org/10.1111/joa.12370

12. de Bruin, M., Smeulders, M.J.C., Kreulen, M., 2011. Flexor carpi ulnaris tenotomy alone does not eliminate its contribution to wrist torque. Clin. Biomech. Bristol Avon 26, 725-728. https://doi.org/10.1016/j.clinbiomech.2011.03.007

13. Diong, J., Héroux, M.E., Gandevia, S.C., Herbert, R.D., 2019. Minimal force transmission between human thumb and index finger muscles under passive conditions. PLOS ONE 14, e0212496. https://doi.org/10.1371/journal.pone.0212496

14. Fede, C., Porzionato, A., Petrelli, L., Fan, C., Pirri, C., Biz, C., De Caro, R., Stecco, C., 2020. Fascia and soft tissues innervation in the human hip and their possible role in post-surgical pain. J. Orthop. Res. Off. Publ. Orthop. Res. Soc. 38, 1646-1654. https://doi.org/10.1002/jor.24665

15. Finni, T., Cronin, N.J., Mayfield, D., Lichtwark, G.A., Cresswell, A.G., 2017. Effects of muscle activation on shear between human soleus and gastrocnemius muscles. Scand. J. Med. Sci. Sports 27, 26-34. https://doi.org/10.1111/sms.12615

16. Freitas, S.R., Antunes, A., Salmon, P., Mendes, B., Firmino, T., Cruz-Montecinos, C., Cerda, M., Vaz, J.R., 2019. Does epimuscular myofascial force transmission occur between the human quadriceps muscles in vivo during passive stretching? J. Biomech. 83, 91-96. https://doi.org/10.1016/j.jbiomech.2018.11.026

17. Grieve, R., Goodwin, F., Alfaki, M., Bourton, A.J., Jeffries, C., Scott, H., 2015. The immediate effect of bilateral self myofascial release on the plantar surface of the feet on hamstring and lumbar spine flexibility: A pilot randomised controlled trial. J. Bodyw. Mov. Ther. 19, 544-552. https://doi.org/10.1016/j.jbmt.2014.12.004

18. Hoffmann, T.C., Glasziou, P.P., Boutron, I., Milne, R., Perera, R., Moher, D., Altman, D.G., Barbour, V., Macdonald, H., Johnston, M., Lamb, S.E., Dixon-Woods, M., McCulloch, P., Wyatt,
J.C., Chan, A.-W., Michie, S., 2014. Better reporting of interventions: template for intervention description and replication (TIDieR) checklist and guide. BMJ 348, g1687. https://doi.org/10.1136/bmj.g1687

19. Huijing, P.A., 2009. Epimuscular myofascial force transmission: a historical review and implications for new research. International Society of Biomechanics Muybridge Award Lecture, Taipei, 2007. J. Biomech. 42, 9-21. https://doi.org/10.1016/j.jbiomech.2008.09.027

20. Huijing, P.A., 2007. Epimuscular myofascial force transmission between antagonistic and synergistic muscles can explain movement limitation in spastic paresis. J. Electromyogr. Kinesiol. Off. J. Int. Soc. Electrophysiol. Kinesiol. 17, 708-724. https://doi.org/10.1016/j.jelekin.2007.02.003

21. Huijing, P.A., Baan, G.C., 2003. Myofascial force transmission: muscle relative position and length determine agonist and synergist muscle force. J. Appl. Physiol. Bethesda Md 1985 94, 1092-1107. https://doi.org/10.1152/japplphysiol.00173.2002

22. Huijing, P.A., Baan, G.C., Rebel, G.T., 1998. Nonmyotendinous force transmission in rat extensor digitorum longus muscle. J. Exp. Biol. 201, 683691.

23. Huijing, P.A., Yaman, A., Ozturk, C., Yucesoy, C.A., 2011. Effects of knee joint angle on global and local strains within human triceps surae muscle: MRI analysis indicating in vivo myofascial force transmission between synergistic muscles. Surg. Radiol. Anat. SRA 33, 869-879. https://doi.org/10.1007/s00276-011-0863-1

24. Joseph, L.H., Hussain, R.I., Naicker, A.S., Htwe, O., Pirunsan, U., Paungmali, A., 2014. Myofascial force transmission in sacroiliac joint dysfunction increases anterior translation of humeral head in contralateral glenohumeral joint. Pol. Ann. Med. 21 , 103-108. https://doi.org/10.1016/j.poamed.2014.07.007

25. Karakuzu, A., Pamuk, U., Ozturk, C., Acar, B., Yucesoy, C.A., 2017. Magnetic resonance and diffusion tensor imaging analyses indicate heterogeneous strains along human medial gastrocnemius fascicles caused by submaximal 
plantar-flexion activity. J. Biomech. 57, 69-78. https://doi.org/10.1016/j.jbiomech.2017.03.028

26. Kf, Schulz., Dg, A., D, M., 2010. CONSORT 2010 statement: updated guidelines for reporting parallel group randomised trials [WWW Document]. BMJ. https://doi.org/10.1136/bmj.c332

27. Krause, F., Wilke, J., Vogt, L., Banzer, W., 2016. Intermuscular force transmission along myofascial chains: a systematic review. J. Anat. 228, 910918. https://doi.org/10.1111/joa.12464

28. Kumka, M., Bonar, J., 2012. Fascia: a morphological description and classification system based on a literature review. J. Can. Chiropr. Assoc. 56, 179-191.

29. Levac, D., Colquhoun, H., O’Brien, K.K., 2010. Scoping studies: advancing the methodology. Implement. Sci. $\quad 5, \quad 69$. https://doi.org/10.1186/1748-5908-5-69

30. Luomala, T., Pihlman, M., 2016. A Practical Guide to Fascial Manipulation: an Evidence-And Clinical-Based Approach (1sted). Elsevier Health Sciences.

31. Maas, H., Sandercock, T.G., 2010. Force transmission between synergistic skeletal muscles through connective tissue linkages. J. Biomed. Biotechnol. 2010, 575672. https://doi.org/10.1155/2010/575672

32. Marinho, H.V.R., Amaral, G.M., Moreira, B.S., Santos, T.R.T., Magalhães, F.A., Souza, T.R., Fonseca, S.T., 2017. Myofascial force transmission in the lower limb: An in vivo experiment. J. Biomech. 63, 55-60. https://doi.org/10.1016/j.jbiomech.2017.07.026

33. Matthews, J.N., Altman, D.G., 1996. Statistics notes. Interaction 2: Compare effect sizes not $\mathrm{P}$ $\begin{array}{llll}\text { values. } & \text { BMJ } & 313, & \end{array}$ https://doi.org/10.1136/bmj.313.7060.808

34. Mense, S., 2019. Innervation of the thoracolumbar fascia. Eur. J. Transl. Myol. 29. https://doi.org/10.4081/ejtm.2019.8297

35. Munn, Z., Peters, M.D.J., Stern, C., Tufanaru, C., McArthur, A., Aromataris, E., 2018. Systematic review or scoping review? Guidance for authors when choosing between a systematic or scoping review approach. BMC Med. Res. Methodol. 18, 143. https://doi.org/10.1186/s12874-018-0611-x

36. Norton-Old, K.J., Schache, A.G., Barker, P.J., Clark, R.A., Harrison, S.M., Briggs, C.A., 2013. Anatomical and mechanical relationship between the proximal attachment of adductor longus and the distal rectus sheath. Clin. Anat. N. Y. N 26, 522-530. https://doi.org/10.1002/ca.22116

37. Oxford Centre for Evidence-Based Medicine: Levels of Evidence (March 2009) - Centre for Evidence-Based Medicine (CEBM), University of Oxford [WWW Document], n.d. URL https://www.cebm.ox.ac.uk/resources/levels-ofevidence/oxford-centre-for-evidence-basedmedicine-levels-of-evidence-march-2009 (accessed 11.2.20)

38. Pamuk, U., Karakuzu, A., Ozturk, C., Acar, B., Yucesoy, C.A., 2016. Combined magnetic resonance and diffusion tensor imaging analyses provide a powerful tool for in vivo assessment of deformation along human muscle fibers. J. Mech. Behav. Biomed. Mater. 63, 207-219. https://doi.org/10.1016/j.jmbbm.2016.06.031

39. Pamuk, U., Yucesoy, C.A., 2015. MRI analyses show that kinesio taping affects much more than just the targeted superficial tissues and causes heterogeneous deformations within the whole limb. J. Biomech. 48, 4262-4270. https://doi.org/10.1016/j.jbiomech.2015.10.036

40. Setia, M.S., 2016. Methodology Series Module 3: Cross-sectional Studies. Indian J. Dermatol. 61, 261-264. https://doi.org/10.4103/00195154.182410

41. Sj, Aboodarda., Aj, S., Dc, B., 2015. Pain pressure threshold of a muscle tender spot increases following local and non-local rolling massage [WWW Document]. BMC Musculoskelet. Disord. https://doi.org/10.1186/s12891-015-0729-5

42. Tian, M., Herbert, R.D., Hoang, P., Gandevia, S.C., Bilston, L.E., 2012. Myofascial force transmission between the human soleus and gastrocnemius muscles during passive knee motion. J. Appl. Physiol. Bethesda Md 1985 113, 517-523. https://doi.org/10.1152/japplphysiol.00111.2012 
43. Tricco, A.C., Lillie, E., Zarin, W., O’Brien, K.K., Colquhoun, H., Levac, D., Moher, D., Peters, M.D.J., Horsley, T., Weeks, L., Hempel, S., Akl, E.A., Chang, C., McGowan, J., Stewart, L., Hartling, L., Aldcroft, A., Wilson, M.G., Garritty, C., Lewin, S., Godfrey, C.M., Macdonald, M.T., Langlois, E.V., Soares-Weiser, K., Moriarty, J., Clifford, T., Tunçalp, Ö., Straus, S.E., 2018. PRISMA Extension for Scoping Reviews (PRISMA-ScR): Checklist and Explanation. Ann. Intern. Med. 169, 467-473. https://doi.org/10.7326/M18-0850

44. Wiewelhove, T., Döweling, A., Schneider, C., Hottenrott, L., Meyer, T., Kellmann, M., Pfeiffer, M., Ferrauti, A., 2019. A Meta-Analysis of the Effects of Foam Rolling on Performance and Recovery. Front. Physiol. 10, 376. https://doi.org/10.3389/fphys.2019.00376

45. Wilke, J., Debelle, H., Tenberg, S., Dilley, A., Maganaris, C., 2020. Ankle Motion Is Associated With Soft Tissue Displacement in the Dorsal Thigh: An in vivo Investigation Suggesting Myofascial Force Transmission Across the Knee Joint. Front. Physiol. 11. https://doi.org/10.3389/fphys.2020.00180

46. Wilke, J., Kalo, K., Niederer, D., Vogt, L., Banzer, W., 2019. Gathering Hints for Myofascial Force Transmission Under In Vivo Conditions: Are Remote Exercise Effects Age Dependent? J. Sport Rehabil. 28, 758-763. https://doi.org/10.1123/jsr.2018-0184

47. Wilke, J., Krause, F., Vogt, L., Banzer, W., 2016a. What Is Evidence-Based About Myofascial Chains: A Systematic Review. Arch. Phys. Med. Rehabil. 97, 454-461. https://doi.org/10.1016/j.apmr.2015.07.023

48. Wilke, J., Niederer, D., Vogt, L., Banzer, W., 2016b. Remote effects of lower limb stretching: preliminary evidence for myofascial connectivity? J. Sports Sci. 34, 2145-2148. https://doi.org/10.1080/02640414.2016.1179776

49. Wilke, Jan, Schleip, R., Klingler, W., Stecco, C., 2017. The Lumbodorsal Fascia as a Potential Source of Low Back Pain: A Narrative Review. BioMed Res. Int. 2017, 5349620. https://doi.org/10.1155/2017/5349620
50. Wilke, J., Schleip, R., Yucesoy, C.A., Banzer, W., 2018. Not merely a protective packing organ? A review of fascia and its force transmission capacity. J. Appl. Physiol. Bethesda Md 1985 124, 234-244.

https://doi.org/10.1152/japplphysiol.00565.2017

51. Wilke, J., Vogt, L., Niederer, D., Banzer, W., 2017. Is remote stretching based on myofascial chains as effective as local exercise? A randomised-controlled trial. J. Sports Sci. 35, 2021-2027. https://doi.org/10.1080/02640414.2016.1251606

52. Woolf, A.D., Pfleger, B., 2003. Burden of major musculoskeletal conditions. Bull. World Health Organ. 81, 646-656.

53. Yaman, A., Ozturk, C., Huijing, P.A., Yucesoy, C.A., 2013. Magnetic resonance imaging assessment of mechanical interactions between human lower leg muscles in vivo. J. Biomech. Eng. $\quad 135$, 91003. https://doi.org/10.1115/1.4024573

54. Yoshitake, Y., Uchida, D., Hirata, K., Mayfield, D.L., Kanehisa, H., 2018. Mechanical interaction between neighboring muscles in human upper limb: Evidence for epimuscular myofascial force transmission in humans. J. Biomech. 74, 150-155. https://doi.org/10.1016/j.jbiomech.2018.04.036

55. Yucesoy, C.A., 2010. Epimuscular myofascial force transmission implies novel principles for muscular mechanics. Exerc. Sport Sci. Rev. 38, 128-134. https://doi.org/10.1097/JES.0b013e3181e372ef 


\section{Table 1}

\begin{tabular}{|c|c|c|c|c|c|c|c|c|c|c|c|}
\hline $\begin{array}{l}\text { SI } \\
\text { No }\end{array}$ & Author/Year & $\begin{array}{l}\text { Study } \\
\text { Design }\end{array}$ & Study Objective & Population & Intervention & $\begin{array}{l}\text { Compariso } \\
\text { n }\end{array}$ & $\begin{array}{l}\text { Outcome } \\
\text { Measure }\end{array}$ & Result & $\begin{array}{c}\text { Study } \\
\text { Quality } \\
\text { (CEBM) }\end{array}$ & $\begin{array}{l}\text { MFT area } \\
\text { Identified }\end{array}$ & $\begin{array}{l}\text { Result } \\
\text { supporting } \\
\text { MFT? }\end{array}$ \\
\hline 1 & $\begin{array}{l}\text { de Bruin et } \\
\text { al., } 2011\end{array}$ & $\begin{array}{c}\text { Clinical } \\
\text { Trial }\end{array}$ & $\begin{array}{l}\text { To determine whether } \\
\text { Flexor carpi ulnaris } \\
\text { muscle still influences } \\
\text { wrist torque even after } \\
\text { tenotomy of its distal } \\
\text { tendon }\end{array}$ & $\begin{array}{l}\text { Total }=15 ; \mathrm{CP} \\
\text { patients } \\
\text { Mean Age }=17 \\
\text { Gender }=\text { Male }\end{array}$ & $\begin{array}{l}\text { Determined in vivo maximal wrist torque } \\
\text { in hemiplegic cerebral palsy patients in } \\
\text { three conditions: 1) with the arm and the } \\
\text { muscle intact; 2) after tenotomy of the } \\
\text { flexor carpi unaris just proximal to the } \\
\text { pisiform bone, with complete release } \\
\text { from its insertion; and 3) after careful } \\
\text { dissection of the belly of the muscle from } \\
\text { its fascial surroundings up until } \\
\text { approximately halfway its length. }\end{array}$ & None & Wrist torque & $\begin{array}{l}\text { After tenotomy of the flexor carpi } \\
\text { ulnaris muscle, the maximal wrist } \\
\text { torque decreased } 18 \% \text { whereas } \\
\text { dissection of the muscle resulted in } \\
\text { an additional decrease of } 18 \% \text {. We } \\
\text { conclude that despite the tenotomy } \\
\text { of its distal tendon, the flexor carpi } \\
\text { ulnaris still contributes to the } \\
\text { flexion torque at the wrist through } \\
\text { myofascial force transmission }\end{array}$ & 4 & $\begin{array}{l}\text { Muscle tendon } \\
\text { of Flexor carpi } \\
\text { ulnaris }\end{array}$ & Likely \\
\hline 2 & $\begin{array}{l}\text { Tian et al., } \\
2012\end{array}$ & $\begin{array}{c}\text { Cross- } \\
\text { sectional } \\
\text { experimental } \\
\text { study }\end{array}$ & $\begin{array}{l}\text { To determine the } \\
\text { degree to which } \\
\text { passive changes in } \\
\text { gastrocnemius muscle } \\
\text { length, induced by } \\
\text { knee } \\
\text { motion, affect the } \\
\text { tension in the adjacent } \\
\text { soleus muscle, and to } \\
\text { quantify the } \\
\text { magnitude of } \\
\text { myofascial passive } \\
\text { force transmission } \\
\text { between } \\
\text { gastrocnemius and } \\
\text { adjacent soleus. }\end{array}$ & $\begin{array}{c}\text { Total }=15 ; \text { Healthy } \\
\text { pop } \\
\text { Age }=29 \pm 4 \\
\text { Gender not } \\
\text { mentioned }\end{array}$ & $\begin{array}{l}\text { Simultaneous ultrasound images of the } \\
\text { gastrocnemius and soleus muscles were } \\
\text { obtained during passive knee flexion }(0- \\
\left.90^{\circ}\right) \text {, while keeping the ankle angle fixed } \\
\text { at either } 70^{\circ} \text { or } 115^{\circ} \text {. }\end{array}$ & None & $\begin{array}{l}\text { Quantification } \\
\text { muscle } \\
\text { fascicle } \\
\text { lengths }\end{array}$ & $\begin{array}{l}\text { This study suggests there may be } \\
\text { some intermuscular force } \\
\text { transmission between the medial } \\
\text { gastrocnemius muscle and soleus } \\
\text { muscle during passive knee } \\
\text { extension }\end{array}$ & 4 & $\begin{array}{l}\text { Between } \\
\text { Gastrocnemius } \\
\text { and Soleus }\end{array}$ & Likely \\
\hline 3 & $\begin{array}{l}\text { do Carmo } \\
\text { Carvalhais et } \\
\text { al., } 2013\end{array}$ & $\begin{array}{c}\text { Cross- } \\
\text { sectional } \\
\text { experimental } \\
\text { study }\end{array}$ & $\begin{array}{l}\text { To provide empirical } \\
\text { evidence of } \\
\text { myofascial force } \\
\text { transmission from } \\
\text { Latissimus dorsi (LD) } \\
\text { to contralateral } \\
\text { gluteus maximus } \\
\text { (Gmax) through } \\
\text { tensor fascia lata } \\
\text { (TFL) in-vivo. }\end{array}$ & $\begin{array}{c}\text { Total }=37 ; \text { Healthy } \\
\text { pop } \\
\text { Age }=24.92 \pm 3.21 \\
\text { Gender }=\text { Male }=15 \\
\text { Female }=22\end{array}$ & $\begin{array}{l}\text { An assessment of passive hip torque } \\
\text { against medial rotation by means of an } \\
\text { isokinetic dynamometer, carried out } \\
\text { under three test conditions: (1) control, } \\
\text { (2) passive LD tensioning and (3) active } \\
\text { LD tensioning. }\end{array}$ & None & LD tensioning & $\begin{array}{l}\text { This study suggests the evidence of } \\
\text { intermuscular force transmission } \\
\text { between the medial gastrocnemius } \\
\text { muscle and soleus muscle during } \\
\text { passive knee extension }\end{array}$ & $3 \mathrm{~b}$ & $\begin{array}{l}\text { From LD to } \\
\text { contralateral } \\
\text { GMax through } \\
\text { TFL in-vivo. }\end{array}$ & Most Likely \\
\hline 4 & $\begin{array}{l}\text { Yaman et al., } \\
2013\end{array}$ & $\begin{array}{c}\text { Cross- } \\
\text { sectional } \\
\text { experimental } \\
\text { study }\end{array}$ & $\begin{array}{l}\text { To test whether global } \\
\text { length changes of } \\
\text { gastrocnemius muscle } \\
\text { tendon complex in } \\
\text { vivo will cause } \\
\text { sizable and } \\
\text { heterogenous local } \\
\text { strains within all } \\
\text { muscle of the human } \\
\text { lower leg }\end{array}$ & $\begin{array}{c}\text { Total }=5 \text {; Healthy } \\
\text { pop } \\
\text { Age }=27 \pm 3 \\
\text { Gender }=\text { Male }\end{array}$ & $\begin{array}{l}\text { Each subject was positioned prone within } \\
\text { MRI scanner. The left leg was brought to } \\
\text { a reference position before the patient } \\
\text { table was moved into MRI bore. The } \\
\text { ankle angle was } 6 \text { to } 90 \text { degree using } \\
\text { AFO . TO keep the orientation of the } \\
\text { lower leg contant, position of the knee } \\
\text { cap \& tip of AFO were marked on the } \\
\text { patient table. The knee angle was } 170 \\
\text { degree }+l-3 \text {. Sets of } 3 D \text { high resolution } \\
\text { MRI were acquired. The hip \& knee } \\
\text { joints were repositioned so that knee } \\
\text { angle was } 150 \text { degree }+/-6 \text { degree and } \\
\text { took the MRI. }\end{array}$ & None & $\begin{array}{l}\text { Local } \\
\text { lengthening } \\
\text { and local } \\
\text { shortening of } \\
\text { specific } \\
\text { muscle } \\
\text { groups at } \\
\text { different } \\
\text { location }\end{array}$ & $\begin{array}{l}\text { MFT is a relevant mechanism in } \\
\text { vivo confirming the study } \\
\text { hypothesis }\end{array}$ & 4 & $\begin{array}{l}\text { Gastrocnemius } \\
\text { muscle tendon } \\
\text { complex (lower } \\
\text { extermity) }\end{array}$ & Most Likely \\
\hline
\end{tabular}




\begin{tabular}{|c|c|c|c|c|c|c|c|c|c|c|c|}
\hline 5 & $\begin{array}{l}\text { Joseph et al., } \\
2014\end{array}$ & $\begin{array}{l}\text { Case control } \\
\text { study/ } \\
\text { clinica trial }\end{array}$ & $\begin{array}{l}\text { To investigate the } \\
\text { biomechanical effect } \\
\text { of SJD on the } \\
\text { contralateral GHJ }\end{array}$ & $\begin{array}{c}\text { Total }=40(20 \mathrm{SJD} \\
20 \text { Healthy }) \text { Age - } \\
\text { SID }=35 \pm 6.2 ; \\
\text { Healthy }=35 \pm 8.1 \\
\text { Gender not } \\
\text { mentioned }\end{array}$ & $\begin{array}{l}\text { A translator force of } 80 \mathrm{~N} \text { using a push- } \\
\text { pull dynamometer to the posterior part of } \\
\text { humeral head to passively translate the } \\
\text { humeral head anteriorly to the point of } \\
\text { end feel. The distance between neck of } \\
\text { scapular and the top of greater tubercle } \\
\text { was measured for resting position of } \\
\text { humeral head (RPHH) and anterior } \\
\text { translation of humeral head (ATHH). }\end{array}$ & $\begin{array}{l}\text { Healthy } \\
\text { matched } \\
\text { contols }\end{array}$ & $\begin{array}{l}\text { RPHH and } \\
\text { ATHH } \\
\text { monitored } \\
\text { using real } \\
\text { time } \\
\text { ultrasound }\end{array}$ & $\begin{array}{l}\text { "Sacroiliac Joint Dysfunction (SJD) } \\
\text { contributes to excessive anterior } \\
\text { translation of humeral head (ATHH) } \\
\text { in the contralateral GHJ. This may } \\
\text { occur due to altered myofascial } \\
\text { force transmission across oblique } \\
\text { sling muscles." }\end{array}$ & $3 \mathrm{~b}$ & $\begin{array}{c}\text { Between } \\
\text { lumbopelvic } \\
\text { region and } \\
\text { contralateral } \\
\text { glenohumeral } \\
\text { joint through } \\
\text { anterior and } \\
\text { posterior } \\
\text { oblique } \\
\text { muscular slings }\end{array}$ & Likely \\
\hline 6 & $\begin{array}{l}\text { Cruz- } \\
\text { Montecinos } \\
\text { et al., } 2015\end{array}$ & $\begin{array}{l}\text { Cross- } \\
\text { sectional } \\
\text { experimental } \\
\text { study }\end{array}$ & $\begin{array}{l}\text { To demonstrate the } \\
\text { relationship between } \\
\text { pelvic motion when } \\
\text { seated with the knees } \\
\text { extended with the } \\
\text { displacement of the } \\
\text { deep fascia of the } \\
\text { Medial } \\
\text { Gastrocnemius (MG) } \\
\text { muscle of the } \\
\text { dominant limb during } \\
\text { pelvic anteversion. }\end{array}$ & $\begin{array}{c}\text { Total }=17 ; \\
\text { Asymptomatic } \\
\text { sedantary } \\
\text { individual } \\
\text { Age }=22.76 \pm 1.8 \\
\text { Gender }=\text { Male }\end{array}$ & $\begin{array}{l}\text { Each individual was asked to perform the } \\
\text { exercise three times. Each task consisted } \\
\text { of moving from maximum retroversion } \\
\text { of the pelvis, with the hips at } 80^{\circ} \text {,knees } \\
\text { fully extended and ankles at } 0^{\circ}, \text { to a } \\
\text { position of pelvic anteversion. Task } \\
\text { execution was standardized with a } \\
\text { metronome, and the individual had to } \\
\text { move from pelvic retroversion to } \\
\text { anteversion within } 4 \mathrm{~s}\end{array}$ & None & $\begin{array}{l}\text { Pelvic Range } \\
\text { of Motion, } \\
\text { displacement } \\
\text { of MG fascia }\end{array}$ & $\begin{array}{l}\text { The results reaffirm and enforce the } \\
\text { functional concept of force } \\
\text { transmission through synergistic } \\
\text { muscle groups and grants new } \\
\text { perspectives for the role of the } \\
\text { fasciae in restricting movement in } \\
\text { remote zones }\end{array}$ & 4 & $\begin{array}{l}\text { Pelvic region to } \\
\text { knee joint and } \\
\text { MG muscle }\end{array}$ & Most Likely \\
\hline 7 & $\begin{array}{c}\text { Grieve et al., } \\
2015\end{array}$ & RCT (pilot) & $\begin{array}{l}\text { To investigate the } \\
\text { immediate effect of a } \\
\text { single application of } \\
\text { self myofascia relaese } \\
\text { (SMR) on the plantar } \\
\text { aspect of the foot, on } \\
\text { hamstring and lumbar } \\
\text { spine flexibility. }\end{array}$ & $\begin{array}{l}\text { Total }=24 \text { healthy } \\
\text { participants }(12 \\
\text { IG;; } 12 \text { CG) Age - } \\
=28 \pm 11.3 ; \\
\text { Healthy } \\
\text { Gender }=8 \text { Male \& } \\
16 \text { Female }\end{array}$ & $\begin{array}{l}\text { Participants randomly allocated to an } \\
\text { intervention (SMR) or control group (no } \\
\text { therapy). Baseline and post intervention } \\
\text { flexibility was assessed by a sit-and- } \\
\text { reach test (SRT). Participants were } \\
\text { instructed to roll a tennis ball on the sole } \\
\text { of each foot from behind the metatarsal } \\
\text { heads to the heel concentrating on the } \\
\text { medial arch for } 2 \text { min. The Intervention } \\
\text { procedure consisted of baseline SRT } \\
\text { measurements, followed by } 4 \text { min of } \\
\text { SMR ( } 2 \text { min per foot) and then post } \\
\text { intervention SRT measurements. }\end{array}$ & $\begin{array}{l}\text { control } \\
\text { group (no } \\
\text { therapy). }\end{array}$ & $\begin{array}{l}\text { Hamstring } \\
\text { and lumbar } \\
\text { flexibility }\end{array}$ & $\begin{array}{l}\text { Efficacy of SMF on one area of a } \\
\text { proposed "anatomy train" and its } \\
\text { global effect on proximal flexibility. } \\
\text { This study has supplied evidence for } \\
\text { the immediate effectiveness of SMR } \\
\text { on the superficial Back line (SBL) } \\
\text { and suggest that asymptomatic } \\
\text { individuals could have an } \\
\text { immediate increase in flexibility of } \\
\text { the hamstrings and lumbar spine } \\
\text { through this intervention. }\end{array}$ & $\begin{array}{c}\text { CEBM=2b; } \\
\text { PEDro= } \\
4 / 10\end{array}$ & $\begin{array}{l}\text { Posterior } \\
\text { myofascial } \\
\text { chain }(\mathrm{SBL})\end{array}$ & Likely \\
\hline 8 & $\begin{array}{c}\text { Pamuk et al., } \\
2016\end{array}$ & $\begin{array}{c}\text { Cross- } \\
\text { sectional } \\
\text { experimental } \\
\text { study }\end{array}$ & $\begin{array}{l}\text { To assess muscle fiber } \\
\text { direction local tissue } \\
\text { deformations within } \\
\text { the human medial } \\
\text { Gastrocnemius (GM) } \\
\text { muscle as caused by } \\
\text { knee angle changes }\end{array}$ & $\begin{array}{c}\text { Total }=5 \text {; Healthy } \\
\text { pop } \\
\text { Age }=27 \pm 1 \\
\text { Gender }=\text { Female }\end{array}$ & $\begin{array}{l}\text { Participants were positioned prone with } \\
\text { in the MR scanner in a relaxed state with } \\
\text { the ankle angle fixed at } 90 \text { degrees. The } \\
\text { knee was brought to f lexion (140.8 } 33 \\
\text { degree) (undeformed state). Sets of } 3 \mathrm{D} \\
\text { high resolution MR, and DT images were } \\
\text { acquired. This protocol was repeated at } \\
\text { extended knee joint position ( } 117 \pm \\
1 \text { degree) (deformed state) }\end{array}$ & None & Shear strain & $\begin{array}{l}\text { In homogeneity of fiber strain } \\
\text { indicates epimuscular myofascial } \\
\text { force transmission. Effects of knee } \\
\text { movement assessed indicate major } \\
\text { strain distribution along human GM } \\
\text { muscle fibers. }\end{array}$ & 4 & $\begin{array}{l}\text { GM } \\
\text { deformation } \\
\text { with respect to } \\
\text { Knee angle } \\
\text { changes }\end{array}$ & Most Likely \\
\hline 9 & $\begin{array}{l}\text { Wilke et al., } \\
2016\end{array}$ & $\begin{array}{l}\text { Pilot } \\
\text { Clinical } \\
\text { Trial } \\
\text { (controlled, } \\
\text { matched- } \\
\text { pairs } \\
\text { intervention } \\
\text { study) }\end{array}$ & $\begin{array}{l}\text { Aimed to address this } \\
\text { research deficit by } \\
\text { investigating the } \\
\text { effectiveness of lower } \\
\text { limb stretching to } \\
\text { increase neck } \\
\text { mobility. }\end{array}$ & $\begin{array}{c}\text { Total }=26 \text { healthy } \\
\text { pop }(13 \text { EG; } 13 \\
\text { CG) Age }=30.3 \pm \\
6.2 ; \\
\text { Gender }=16 \text { Male; } \\
10 \text { Female }\end{array}$ & $\begin{array}{l}\text { One group }(\mathrm{n}=13) \text { performed three } 30 \mathrm{~s} \\
\text { bouts of static stretching for the } \\
\text { gastrocnemius and the hamstrings, } \\
\text { respectively. An age- and sex-matched } \\
\text { control group (CG; } \mathrm{n}=13 \text { ) remained } \\
\text { inactive. Pre- and post-intervention, } \\
\text { maximal cervical ROM in } \\
\text { flexion/extension was assessed. }\end{array}$ & $\begin{array}{l}\text { Age and } \\
\text { gender } \\
\text { matched } \\
\text { control } \\
\text { group } \\
(\mathrm{n}=13)\end{array}$ & $\begin{array}{c}\text { Maximal } \\
\text { Cervical } \\
\text { ROM }\end{array}$ & $\begin{array}{l}\text { A single session of static stretching } \\
\text { might elicit acute flexibility } \\
\text { increases at distant joints. Strain } \\
\text { transfer via myofascial meridians } \\
\text { represents a plausible explanation } \\
\text { for this finding }\end{array}$ & $3 \mathrm{~b}$ & $\begin{array}{c}\text { Myofascial } \\
\text { chain linking } \\
\text { lower limbs } \\
\text { with cervical } \\
\text { ROM }\end{array}$ & Most Likely \\
\hline 10 & $\begin{array}{l}\text { Wilke et al., } \\
2017\end{array}$ & RCT & $\begin{array}{l}\text { Investigated the } \\
\text { remote effectiveness } \\
\text { vs lower limb } \\
\text { stretching vs local } \\
\text { cervical stretching on } \\
\text { neck ROM }\end{array}$ & $\begin{array}{c}\text { Total= }=63 \text { healthy } \\
\text { pop }(36 \pm 13 \text { years, } \\
\delta 32) \text { were } \\
\text { randomly assigned } \\
\text { to one of three } \\
\text { groups }\end{array}$ & $\begin{array}{l}\text { Remote stretching of the lower limb } \\
\text { (LLS), local stretching of the cervical } \\
\text { spine (CSS) or inactive control (CON). } \\
\text { Prior (M1), immediately post (M2) and } 5 \\
\text { min following intervention (M3), } \\
\text { maximal cervical ROM was assessed }\end{array}$ & $\begin{array}{l}\text { Inactive } \\
\text { controls }\end{array}$ & $\begin{array}{c}\text { maximal } \\
\text { Cervical } \\
\text { ROM }\end{array}$ & $\begin{array}{l}\text { Both LLS and CSS increased } \\
\text { cervical ROM compared to the } \\
\text { control group in all movement } \\
\text { planes and at all measurements ( } \mathrm{P}< \\
\text {.05). Between LLS and CSS, no } \\
\text { statistical differences were found (P } \\
>.05 \text { ). }\end{array}$ & $\begin{array}{c}\text { CEBM }=2 \mathrm{~b} ; \\
\text { PEDro= } \\
6 / 10\end{array}$ & $\begin{array}{l}\text { Myofascial } \\
\text { chain linking } \\
\text { lower limbs } \\
\text { with cervical } \\
\text { ROM }\end{array}$ & Most likely \\
\hline
\end{tabular}




\begin{tabular}{|c|c|c|c|c|c|c|c|c|c|c|c|}
\hline 11 & $\begin{array}{l}\text { Finnie te al. } \\
2017\end{array}$ & $\begin{array}{c}\text { Cross- } \\
\text { sectional } \\
\text { experimental } \\
\text { study }\end{array}$ & $\begin{array}{l}\text { To elucidate whether } \\
\text { MFT pathways have } \\
\text { functional roles in } \\
\text { vivoe xamined } \\
\text { whether activation } \\
\text { could alter the shear } \\
\text { between the Soleus } \\
\text { (SOL) and lateral } \\
\text { Gastrochemius (LG) } \\
\text { muscles. }\end{array}$ & $\begin{array}{c}\text { Total }=11 \text {; Healthy } \\
\text { pop } \\
\text { Age }=29 \pm 6 \\
\text { Gender not } \\
\text { mentioned }\end{array}$ & $\begin{array}{l}\text { A series of knee joint manipulations } \\
\text { where plantart flexion force, LG, and } \\
\text { SOL muscle fascicle lengths and relative } \\
\text { displacement of aponeurosese between the } \\
\text { muscles were obtained. Data during a } \\
\text { passive full range of motion were } \\
\text { recorded, followed by } 20^{\circ} \text { knee extension } \\
\text { stretches in both passive conditions and } \\
\text { with selective electrical stimulation of } \\
\text { LG. }\end{array}$ & None & $\begin{array}{c}\text { Relative } \\
\text { displacement } \\
\text { of SOL and } \\
\text { LG } \\
\text { apponeurosis }\end{array}$ & 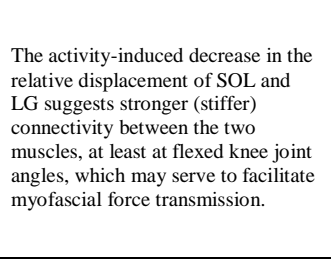 & 4 & $\begin{array}{c}\text { Soleus and } \\
\text { lateral } \\
\text { Gastronemius }\end{array}$ & Likely \\
\hline 12 & $\begin{array}{l}\text { Marinho et } \\
\text { al., } 2017\end{array}$ & $\begin{array}{c}\text { Cross- } \\
\text { sectional } \\
\text { experimental } \\
\text { study }\end{array}$ & $\begin{array}{l}\text { To verify how } \\
\text { simultaneous } \\
\text { changes on kneer/hip } \\
\text { positions modify the } \\
\text { ankle's resting } \\
\text { position and passive } \\
\text { torque. }\end{array}$ & $\begin{array}{c}\text { Total }=37 ; \text { Healthy } \\
\text { pop } \\
\text { gge }=23.97 \pm 3.48 \\
\text { Gender= male \& } \\
\text { female }\end{array}$ & 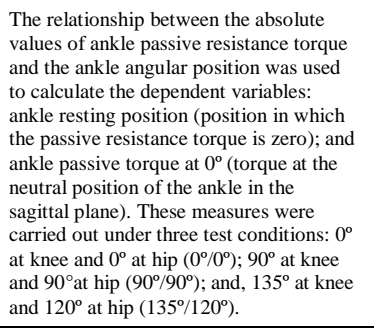 & None & $\begin{array}{l}\text { Ankle passive } \\
\text { resistance } \\
\text { torque and the } \\
\text { ankle angular } \\
\text { position }\end{array}$ & 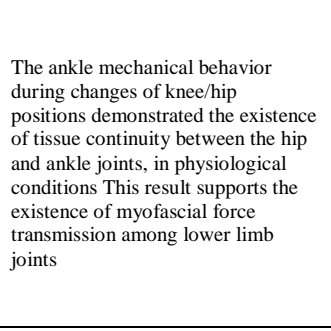 & 4 & $\begin{array}{c}\text { Lower limb } \\
\text { muscles }\end{array}$ & Most Likely \\
\hline 13 & $\begin{array}{l}\text { Karakuzu et } \\
\text { al., 2017 }\end{array}$ & $\begin{array}{c}\text { Cross- } \\
\text { sectional } \\
\text { experimental } \\
\text { study }\end{array}$ & 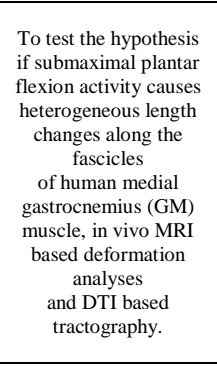 & $\begin{array}{l}5 \text { Healthy pop; Age } \\
=26 \pm 3 \text {; Gender } \\
\text { =Female }\end{array}$ & $\begin{array}{l}\text { Each subject was positioned in a } 3 \mathrm{~T} \\
\text { clinical MR scanner in prone position. } \\
\text { The right foot was firmly fastened to the } \\
\text { custom-built MRI compatible foot pedal } \\
\text { at an ankle angle of } 90 \text { degrees.In relaxed } \\
\text { condition of the subjects, image } \\
\text { acquisition was done (undeformed state). } \\
\text { Subsequently, the subjects performed. } \\
\text { sustained isometric plantarf flexion at } \\
15 \% \text { MVC and maintained that during a } \\
\text { second image acquisition (deformed } \\
\text { state). Separate sets of } 3 \mathrm{D} \text { high- } \\
\text { resolution anatomical (MR) and diffusion } \\
\text { images (DT) were acquired for both } \\
\text { states. }\end{array}$ & None & Fascicle strain & $\begin{array}{l}\text { Conclude that submaximal plantar } \\
\text { flexion activity causes a } \\
\text { heterogeneous distribution of strain } \\
\text { within the GM fascicles }\end{array}$ & 4 & $\begin{array}{c}\text { Medial } \\
\text { Gastrocnemius }\end{array}$ & Most likely \\
\hline 14 & $\begin{array}{l}\text { Yoshitake et } \\
\text { al., 2018 }\end{array}$ & $\begin{array}{c}\text { Cross- } \\
\text { sectional } \\
\text { experimental } \\
\text { study }\end{array}$ & $\begin{array}{l}\text { To examine if the } \\
\text { shear modulus of a } \\
\text { resting musclis } \\
\text { attered when joint } \\
\text { angle is manipulated } \\
\text { to } \\
\text { passively stretch a } \\
\text { neighboring muscle in } \\
\text { the distal direction } \\
\text { and } \\
\text { it the effect of passive } \\
\text { muscle stretch on } \\
\text { shear moludus shows } \\
\text { regional differences. }\end{array}$ & $\begin{array}{c}\text { Total }=13 ; \text { Healthy } \\
\text { pop } \\
\text { Age }=21.6 \pm 2.7 \\
\text { Gender }=\text { Male }\end{array}$ & $\begin{array}{l}\text { The shear modulus of Biceps Brachii } \\
\text { (BB) and Brachialis (BRA) was } \\
\text { measured with whear-wave elastography } \\
\text { at proximal and distal muscle regions for } \\
\text { three forearm positions and with the } \\
\text { elbow joint angle at either } 100 \text { deg or } 160 \\
\text { deg. }\end{array}$ & None & $\begin{array}{l}\text { Shear } \\
\text { Modulus }\end{array}$ & $\begin{array}{l}\text { Epimuscular myofascial force } \\
\text { transmission may be facilitated at } \\
\text { stretched muscle lengths. }\end{array}$ & 4 & $\begin{array}{l}\text { Biceps Brachi } \\
\text { and Brachialis }\end{array}$ & Likely \\
\hline 15 & $\begin{array}{l}\text { Ates et al, } \\
2018\end{array}$ & $\begin{array}{c}\text { Cross- } \\
\text { sectional } \\
\text { experimental } \\
\text { study }\end{array}$ & $\begin{array}{l}\text { To quantify the } \\
\text { localized changes } \\
\text { in the shear modulus } \\
\text { of the gastronemius } \\
\text { lateralis (GL), } \\
\text { monoartiticular dorsi- } \\
\text { and plantarflexor } \\
\text { muscles induced by a } \\
\text { change in knee angle. }\end{array}$ & 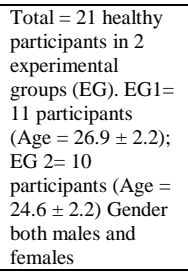 & $\begin{array}{l}\text { Participants underwent slow passive } \\
\text { ankle cotatitions at the following two knee } \\
\text { positions: knee flexed at } 90^{\circ} \text { and knee } \\
\text { fully extended.This was } \\
\text { performed during two experimental } \\
\text { sessions }\end{array}$ & $\begin{array}{c}\text { Between } \\
\text { group } \\
\text { comparison } \\
\text { of two } \\
\text { different } \\
\text { experiment } \\
\text { al } \\
\text { conditions }\end{array}$ & $\begin{array}{c}\text { Shear } \\
\text { Modulus }\end{array}$ & $\begin{array}{l}\text { As the muscle shear modulus is } \\
\text { linearly related to passive muscle } \\
\text { force, theseresults provide evidence } \\
\text { of a nonnegligible intermuscular } \\
\text { mechanical interaction between the } \\
\text { human lower leg muscles during } \\
\text { passive ankle rotations. }\end{array}$ & 4 & $\begin{array}{c}\text { GL, soleus } \\
\text { (proximal \& } \\
\text { distal), } \\
\text { peroneus } \\
\text { longus (PERL), } \\
\text { and tibialis } \\
\text { anterior (TA) }\end{array}$ & Likely \\
\hline
\end{tabular}




\begin{tabular}{|c|c|c|c|c|c|c|c|c|c|c|c|}
\hline 16 & $\begin{array}{l}\text { Wilke et al., } \\
2018\end{array}$ & $\begin{array}{l}\text { Clincal trial } \\
\text { (regression } \\
\text { analysis } \\
\text { trial) }\end{array}$ & $\begin{array}{l}\text { To examine the age- } \\
\text { dependency of non- } \\
\text { local exercise effects } \\
\text { following plantar } \\
\text { fascia self myofascial } \\
\text { release (SMR). }\end{array}$ & $\begin{array}{c}\text { Total }=168 ; \\
\text { Healthy subjects } \\
\text { Age }=45 \pm 21 ; \\
\text { male \& female }\end{array}$ & $\begin{array}{l}\text { All participants bilaterally performed one } \\
120 \text { sout of SMR at the plantar foot } \\
\text { (total treatment duration: } 4 \text { minutes). } \\
\text { With a foam ball, they bilaterally } \\
\text { massaged the plantar aponeurosis, rolling } \\
\text { gently between origin and insertion in the } \\
\text { upright standing position. Prior to and } \\
\text { post intervention, sit and reach tests were } \\
\text { conducted in order to estimate hamstring } \\
\text { flexibility. }\end{array}$ & None & $\begin{array}{l}\text { Hamstring } \\
\text { flexibility }\end{array}$ & $\begin{array}{l}\text { Plantar foot SMR increases } \\
\text { hamstring extensibility, which is } \\
\text { explained by age to a small degree. } \\
\text { Additional research is warranted in } \\
\text { order to delineate the substrate of } \\
\text { remote exercise effects. Besides } \\
\text { mechanical force transmission, also } \\
\text { cortical adaptations might represent } \\
\text { the driving factor. }\end{array}$ & $3 b$ & $\begin{array}{c}\text { Plantar muscles } \\
\text { and hamstring } \\
\text { muscles }\end{array}$ & Likely \\
\hline 17 & $\begin{array}{l}\text { Freitas et al., } \\
\quad 2019\end{array}$ & $\begin{array}{l}\text { Cross- } \\
\text { sectional } \\
\text { experimental } \\
\text { study }\end{array}$ & $\begin{array}{l}\text { MFT between the } \\
\text { muscles of quadriceps } \\
\text { during passive knee } \\
\text { flexion }\end{array}$ & $\begin{array}{l}\text { Total }=12 ; \text { Healthy } \\
\text { pop; } \\
\text { Age }=23.7 \pm 3.6 \\
\text { Gender }=\text { Male }\end{array}$ & $\begin{array}{l}\text { Passive knee flextion with hip flexors at } \\
2 \text { length with hip position } 80 \text { degree and } \\
0 \text { degree. Twelve stretching trials for } \\
\text { each hip position. } \\
\text { with } 1 \text {-min rest between trials, as two } \\
\text { repetitions were performed for each } \\
\text { muscle region (i.e., } 3 \text { muscles, } 2 \text { regions, } \\
2 \text { repetitions). At the end of the protocol, } \\
\text { two 4-s maximal knee extension } \\
\text { isometric contractions were performed } \\
\text { (with the knee and hip fixed at } 80 \text { deg } \\
\text { flexion) in order to normalize EMG } \\
\text { signals. }\end{array}$ & None & $\begin{array}{c}\text { Shear wave } \\
\text { elastography - } \\
\text { Shear } \\
\text { modulus of } \\
\text { Quadriceps }\end{array}$ & $\begin{array}{l}\text { The in vivo shear modulus of the } \\
\text { vastus lateralis and vastus medialis } \\
\text { of healthy individuals remained } \\
\text { unchanged between two hip } \\
\text { positions during passive knee } \\
\text { flexion up to } 90 \text { degree. } \\
\text { Epimuscular myofascial force } \\
\text { transmission (at a muscle belly } \\
\text { level) does not occur between the } \\
\text { quadriceps muscles when passively } \\
\text { flexing the knee until } 90 \text { degrees. }\end{array}$ & $3 b$ & $\begin{array}{l}\text { Between } \\
\text { Quadriceps } \\
\text { Muscles }\end{array}$ & Less Likely \\
\hline 18 & $\begin{array}{c}\text { Diong et al., } \\
2019\end{array}$ & $\begin{array}{l}\text { Cross- } \\
\text { sectional } \\
\text { experimental } \\
\text { study }\end{array}$ & $\begin{array}{c}\text { To investigate } \\
\text { intermuscle force } \\
\text { transmission between } \\
\text { human flexor pollicis } \\
\text { longus } \\
\text { and the index finger } \\
\text { part of flexor } \\
\text { digitorum profundus }\end{array}$ & $\begin{array}{c}15 \text { healthy subjects } \\
\text { Age }=44 \pm 11 \\
\text { Gender }=8 \text { Female } \\
\& 7 \text { Male }\end{array}$ & $\begin{array}{l}\text { Subjects first performed two index finger } \\
\text { distal interphalangeal flexion MVCs } \\
\text { against the load cell. Next, the removable } \\
\text { post was adjusted to extend the thumb } \\
\text { using } 6 \mathrm{~N} \text {, and the position of the post } \\
\text { was marked before the thumb was } \\
\text { released. Finally, the thumb } \\
\text { interphalangeal joint was passively } \\
\text { flexed and extended by an investigator to } \\
\text { determine the limits of range of } \\
\text { motion. }\end{array}$ & None & $\begin{array}{l}\text { Intermuscle } \\
\text { force } \\
\text { transmission }\end{array}$ & $\begin{array}{c}\text { Findings indicate that intermuscle } \\
\text { force transmission occurs between } \\
\text { the } \\
\text { thumb and index finger muscles } \\
\text { under passive physiological } \\
\text { conditions }\end{array}$ & 4 & $\begin{array}{l}\text { Flexor pollicis } \\
\text { longus and } \\
\text { flexor } \\
\text { digitorum } \\
\text { profundus }\end{array}$ & Most likely \\
\hline 19 & $\begin{array}{l}\text { Wilke et al., } \\
2020\end{array}$ & $\begin{array}{l}\text { Cross- } \\
\text { sectional } \\
\text { experimental } \\
\text { study }\end{array}$ & $\begin{array}{l}\text { To examine the } \\
\text { impact of ankle } \\
\text { motion on soft tissue } \\
\text { displacement of the } \\
\text { dorsal thigh }\end{array}$ & $\begin{array}{l}11 \text { healthy active } \\
\text { individuals ( } 26.8 \pm \\
4.3 \text { years; } 6 \text { Males), }\end{array}$ & $\begin{array}{l}\text { Healthy active individuals in prone } \\
\text { position and with the knee extended, } \\
\text { underwent passive calf stretches (ankle } \\
\text { dorsal extension) imposed by an } \\
\text { isokinetic dynamometer. High-resolution } \\
\text { ultrasound was used to simultaneously } \\
\text { capture the displacement of the } \\
\text { semimembranosus muscle, which was } \\
\text { quantified by means of cross-correlation } \\
\text { analysis. Inactivity of the leg muscles } \\
\text { was controlled using surface } \\
\text { electromyography (EMG). }\end{array}$ & None & $\begin{array}{l}\text { Ultrasound } \\
\text { recorded } \\
\text { tissue } \\
\text { displacement }\end{array}$ & $\begin{array}{l}\text { Initial in vivo evidence for a } \\
\text { mechanical force transmission } \\
\text { between serially connected skeletal } \\
\text { muscles. This means that local } \\
\text { alterations of the mechanical tissue } \\
\text { properties may modify flexibility in } \\
\text { neighboring (superior or inferior) } \\
\text { joints. }\end{array}$ & 4 & $\begin{array}{l}\text { Posterior lower } \\
\text { leg (hamstrimg } \\
\text { and calf) - } \\
\text { dorsal thigh } \\
\text { (MFT across } \\
\text { knee joint) }\end{array}$ & Most likely \\
\hline
\end{tabular}




\section{Figure 1}

\section{APPENDIX \\ PRISMA Flow Diagram}

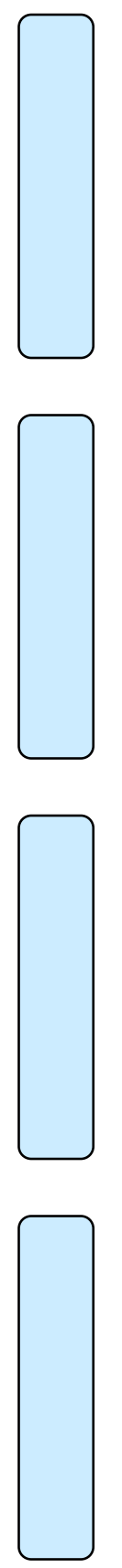
Records identified through database searching
$(\mathrm{n}=238)$

Additional records identified through other sources $(\mathrm{n}=21)$

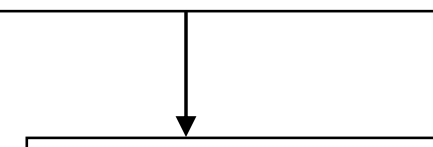
Records excluded $(n=134)$

Records after initial screening and duplicates removed

$$
(\mathrm{n}=160)
$$

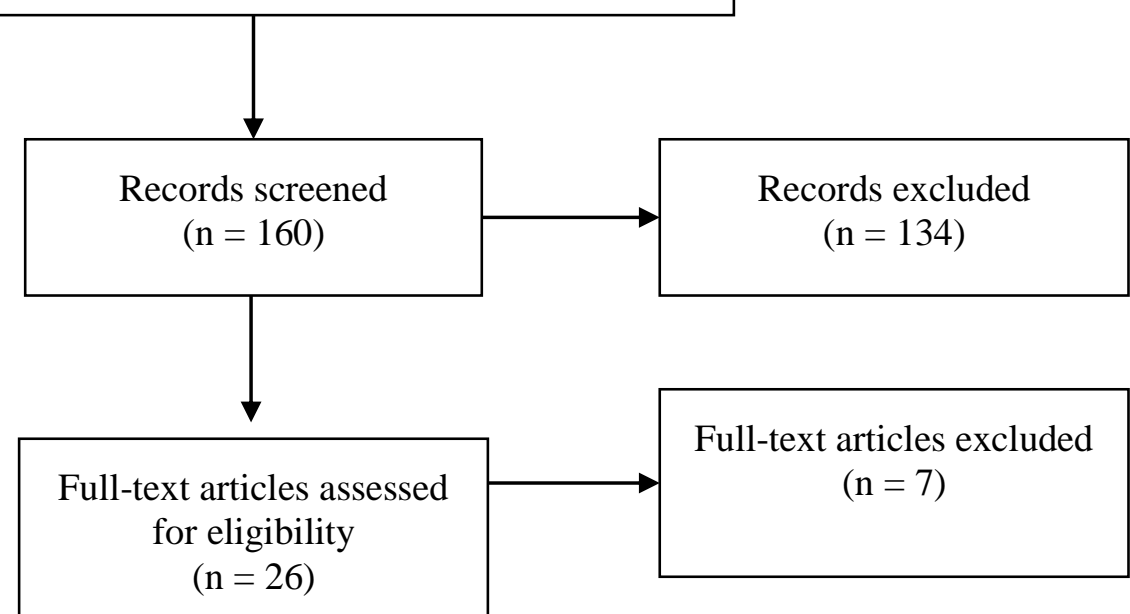

Studies included in qualitative synthesis

$$
(n=19)
$$

